\title{
Constraint Analysis of Groundnut Cultivation in YSR District of Andhra Pradesh, India
}

\author{
A. Veeraiah ${ }^{1}$, V. Shilpakala ${ }^{1^{*}}$, S. Ramalakshmi Devi ${ }^{2}$ and K. Ankaiah Kumar ${ }^{2}$ \\ ${ }^{1}$ District Agricultural Advisory and Transfer of Technology Centre, India \\ ${ }^{2}$ Krishi Vigyan Kendra, Utukur, Kadapa, YSR District, Andhra Pradesh - 516003, India
}

*Corresponding author

\section{A B S T R A C T}

Groundnut (Arachis hypogea L.,) is one of the world's important crops, ranking fifth in oil production. Groundnut seed is a rich food source providing quality vegetable oil (48\%-50\%), protein (26\%-28\%), dietary fibre, minerals and

Keywords

Groundnut,

Constraints

analysis, Farmers,

Problems

Article Info

Accepted:

12 June 2019

Available Online:

10 July 2019 vitamins. Total world production of Groundnut was 47 million tonnes from 27 million hectares. In Andhra Pradesh Groundnut is cultivated in 7.35 lakh hectares with 10.43 lakh tonnes production and $1426 \mathrm{~kg} / \mathrm{ha}$ productivity. The Groundnut area of YSR district is decreasing and same trend reflected in production and productivity also. In view of the above the present investigation was designed to study the constraints of farmers in Groundnut cultivation in YSR district. The data was collected through interview schedule designed for the purpose. Statistical tools like frequencies, percentages, and rankings were used. The results showed that non-availability of new varieties of seed material, high cost of fertilisers, lack of knowledge on recommended pesticides for each pest and disease, high cost of labour, complications in adoption of improved technology, inadequate quantity of credit, high cost of labour for harvesting, low market price to the produce and occurrence of drought were the important constraints perceived by the majority of respondents.

\section{Introduction}

Groundnut (Arachis hypogea L.,) is one of the world's important crops, ranking fifth in oil production. In addition, Rhizobia, in association with Groundnut plant fix atmospheric nitrogen into the soil, which improves soil fertility. Groundnut seed is a rich food source providing quality vegetable oil $(48 \%-50 \%)$, Protein $(26-28 \%)$, dietary fibre, minerals and vitamins (Pasupuleti et al., 2013). Globally Groundnut is grown in more than 100 countries situated in tropical, subtropical and worm temperate regions (Upadyay et al., 2012). Total world production of Groundnut was 47 million tonnes from 27 million hectares. China, India, Nigeria, USA, Sudan, Myanmar, Indonesia and Senegal are the major countries producing Groundnut. The average yield of Groundnut 
among the Groundnut growing countries in the world varies between $300 \mathrm{~kg}$ and $5400 \mathrm{~kg} / \mathrm{ha}$. During 2017, India produced 9.18 million tonnes from 5.3 million hectares with a productivity level of $1732 \mathrm{~kg} / \mathrm{ha}$. Six states namely Andhra Pradesh, Gujarath, Karnataka, Maharashtra, Rajasthan and Tamilnadu account for $90 \%$ of the total Groundnut area of the country. In AP Groundnut is cultivated in 7.35 lakhs hectares with 10.48 lakh tonnes production and $1426 \mathrm{~kg} / \mathrm{ha}$ yield. Y.S.R Kadapa is one of the potential districts for Groundnut in Andhra Pradesh with average sown area 44,000 hectares and production of 71,000 tonnes, and $2667 \mathrm{~kg} / \mathrm{ha}$ yield.

The groundnut area database of Y.S.R Kadapa (Table 1) reveals that decrease in the area sown, even in production and productivity. In spite of moderate gains in productivity in India, there remains a large gap in potential yield and yield realized at the farm level, particularly in rain fed agriculture. To design a focussed research programme to attain good yield gains in a consistent manner Identification of major constraints in Groundnut cultivation and ranking them in order of their intensity is very much needed.

\section{Materials and Methods}

The present study was conducted in Y.S.R district of Andhra Pradesh during 2018 with the sample size of 60 respondents by DAATTC and Krishi Vigyan Kendra, Utukur Scientists. The ex-post-facto research design was used for the study. Out of twelve agricultural divisions, six divisions were purposively selected viz., Kamalapuram, Muddanuru, Pulivendula, Kadapa, Rayachoty, Lakkireddypalli. Ten farmers from each agricultural division were selected for the study purposively to determine farmers' perception towards constraints in Groundnut cultivation. For measuring the constraints, interview schedule was developed and response was recorded in the schedule itself. The frequency and percentage for each constraint was worked out and ranking was given.

\section{Results and Discussion}

\section{Characteristics of respondents}

The data (Table 2) indicated that majority $(45 \%)$ of the respondents were from high age group ( 51 \& above) followed by 38 and 17 percent from middle and young age group respectively. This might be due to the fact that only high age group farmers still doing farming and young age farmers moved to urban areas for business. In case of education, majority of the respondents were educated up to high school level, whereas 20 per cent up to primary school level, 18 percent up to degree $\&$ above, 15 Percent up to Intermediate and 13 Percent were illiterate. Bonla et al., (2018) corroborated that Education level affects the adoption of new technologies, and thus the strategies for introduction of new varieties and new agronomic practices.

The data (Table 2) revealed that majority $(42 \%)$ of the respondents having more $(21 \&$ above years) farming experience, whereas 30 and 28 percent respondents were from medium and low experience. This might be due to majority of the farmers were belonged to high age group.

In case of land holding, 60 percent of respondents had small land holding, whereas 15 percent had large, 13 percent had medium and 12 percent had marginal land holdings. Likewise when the data regarding annual income of respondents revealed that majority (75\%) were getting less than one lakh income per annum followed by 25 percent respondents could able to get 1-2 lakhs per annum and no respondents was earning more than 2 lakhs per annum. This might be due to small land 
holdings and also lower prices for farm produce of respondents.

The data (Table 2) regarding sources of information revealed that majority of the respondents were receiving information about agriculture from MAO's, followed by 27 percent from neighbours, 18 percent from AEO's, 10 percent from Scientists, 7 percent from Input dealers and none of them were receiving from ADA. This might be due to availability of MAO's nearer to them at mandal level only.

When the data (Table 2) of extension contact was seen, it revealed that the majority of the respondents $(57 \%)$ are maintaining medium range of extension contacts, whereas 23 and 20 percent of them were maintained frequently and rarely. Similarly, the data of social participation indicates that majority (67\%) did not have membership in any organization and 33 percent of them had membership in one organization.

The data (Table 2) indicated that majority of the respondents $(82 \%)$ from family size is up to 5 followed by above $5(18 \%)$. In case of family type majority of the respondents $(65 \%)$ are from nuclear families followed 35 percent from Joint families.

\section{Constraints analysis of groundnut cultivation}

The major constraints in the Groundnut cultivation identified Viz., Seed, Manures \& Fertilisers Insecticides \& Pesticides, Labour, Technical constraints. Financial constraints, constraints related to cost, Marketing constraints and General constraints; under each head key constraints were given in the Interview schedule for collection of data, in different parts of the district. The Interview schedule was prepared with broad heads and specific heads.

\section{Seed}

In case of Seed (Table 3) majority (51.6\%) Non - availability of seed material of new varieties was the major constraint followed by lack of knowledge about improved varieties (26.6\%), 10 percent of them felt that the replacement of variety was very difficult and only 3.3 percent expressed problem with low germination percentage.

In case of Manures \& Fertilisers (Table 3) majority $(88.3 \%)$ farmers expressed fertilisers cost was very high. 3.3 percent of them felt there was shortage of fertilisers as constraint, 1.6 percent expressed there is under bagging of fertilisers. When we observe the data, there was no problem with regard to availability of manures fertilisers in time. The data (Table 3) regarding Insecticides \& Pesticides revealed that majority $(50 \%)$ of them expressed lack of knowledge on recommended pesticides for each pest and disease. 10 percent of them expressed difficulty to prepare the recommended concentration of solutions, 8.3 percent faced problem in availability of insecticides and pesticides in time.

When labour was taken as the constraint the data (Table 3) indicated that high cost of the labour $(66.7 \%)$ was the major constraint which hold 1 rank among other problems, 10.0 percent of the respondent felt non availability of labour during peak period and only 3.3 percent expressed difficulty in availability of skilled labour, where as 20 percent of them responded that for the cultivation of Groundnut crop from seed to seed there was high labour requirement.

The present findings are in accordance with Hemendra et al., (2014) where he revealed that among the variable costs, the highest cost $(22.6 \%)$ was recorded for casual hired labour followed of imputed value of family labour $(18 \%)$ and seed (11.4\%). 
Table.1 Groundnut database of YSR district for the past seven years

\begin{tabular}{|c|c|c|c|c|c|}
\hline Year & Rainfall $(\mathrm{mm}) /$ year & Season & Area (ha) & Production (tonnes) & Productivity (kg/ha) \\
\hline \multirow{2}{*}{ 2012-13 } & \multirow{2}{*}{597.8} & Kharif & 44179 & 11133.1 & 252 \\
\hline & & Rabi & 20395 & 31959 & 1567 \\
\hline \multirow[t]{2}{*}{ 2013-14 } & \multirow[t]{2}{*}{717.4} & Kharif & 42251 & 38110.4 & 902 \\
\hline & & Rabi & 17336 & 35365.4 & 2040 \\
\hline \multirow[t]{2}{*}{ 2014-15 } & \multirow[t]{2}{*}{411.3} & Kharif & 15754 & 6963.27 & 442 \\
\hline & & Rabi & 11588 & 15435.2 & 1332 \\
\hline \multirow[t]{2}{*}{ 2015-16 } & \multirow[t]{2}{*}{958.8} & Kharif & 28676 & 36619.3 & 1277 \\
\hline & & Rabi & 22124 & 47323.2 & 2139 \\
\hline \multirow[t]{2}{*}{ 2016-17 } & \multirow[t]{2}{*}{448.7} & Kharif & 52015 & 19558 & 376 \\
\hline & & Rabi & 13396 & 45988 & 3433 \\
\hline \multirow[t]{2}{*}{ 2017-18 } & \multirow[t]{2}{*}{742.30} & Kharif & 25315 & 39491 & 1560 \\
\hline & & Rabi & 18171 & 30673 & 1688 \\
\hline \multirow[t]{2}{*}{ 2018-19 } & \multirow[t]{2}{*}{311.0} & Kharif & 8627 & 8419.95 & 976 \\
\hline & & Rabi & 11,113 & 23630.68 & 2126 \\
\hline
\end{tabular}

Table.2 Profile characteristics of farmers

\begin{tabular}{|c|c|c|c|c|}
\hline S. No. & Particulars & Category & Frequency & Percentage \\
\hline \multirow[t]{3}{*}{1.} & \multirow[t]{3}{*}{ Age } & Young (upto 35) & 10 & 17 \\
\hline & & Middle $(36-50)$ & 23 & 38 \\
\hline & & High (51 and above) & 27 & 45 \\
\hline \multirow[t]{5}{*}{2.} & \multirow[t]{5}{*}{ Education } & Illiterate & 8 & 13 \\
\hline & & Primary school & 2 & 20 \\
\hline & & High school & 20 & 34 \\
\hline & & Inter & 09 & 15 \\
\hline & & Degree \& above & 11 & 18 \\
\hline \multirow[t]{3}{*}{3.} & \multirow{3}{*}{ Farming Experience } & Up to 10 Years & 17 & 28 \\
\hline & & $11-20$ & 18 & 30 \\
\hline & & 21 and above & 25 & 42 \\
\hline \multirow[t]{4}{*}{4.} & \multirow[t]{4}{*}{ Size of holding } & Marginal (upto 1ha) & 7 & 12 \\
\hline & & Small (1-2.5 ha) & 36 & 60 \\
\hline & & Medium $(2.5-5$ ha $)$ & 08 & 13 \\
\hline & & Large (5 ha and above) & 09 & 15 \\
\hline \multirow[t]{3}{*}{5.} & \multirow[t]{3}{*}{ Annual Income } & Upto 1 Lakh & 45 & 75 \\
\hline & & 1-2 Lakhs & 15 & 25 \\
\hline & & Above 2 Lakhs & -- & -- \\
\hline \multirow[t]{6}{*}{6.} & \multirow[t]{6}{*}{ Sources of Information } & Scientists & 6 & 10.00 \\
\hline & & ADA's & -- & -- \\
\hline & & MAO 's & 23 & 38.00 \\
\hline & & AEO ‘s & 11 & 18 \\
\hline & & Neighbours & 16 & 27.00 \\
\hline & & Input dealers & 04 & 7.00 \\
\hline \multirow[t]{2}{*}{7.} & \multirow[t]{2}{*}{ Family Size } & Upto 5 & 49 & 82 \\
\hline & & above 5 & 11 & 18 \\
\hline \multirow[t]{2}{*}{8.} & \multirow{2}{*}{ Family Type } & Joint & 21 & 35 \\
\hline & & Nuclear & 39 & 65 \\
\hline \multirow[t]{2}{*}{9.} & \multirow[t]{2}{*}{ Social participation } & No membership & 40 & 67 \\
\hline & & Membership in one organization & 20 & 33 \\
\hline \multirow[t]{3}{*}{10.} & \multirow[t]{3}{*}{ Extension contact } & Frequently & 14 & 23.0 \\
\hline & & Some times & 34 & 57.0 \\
\hline & & Rarely & 12 & 20.0 \\
\hline
\end{tabular}


Table.3 Constraints perceived by the farmers

\begin{tabular}{|c|c|c|c|c|}
\hline S. No. & Constraints perceived by the farmers & Frequency & percentage & Rank \\
\hline \multicolumn{5}{|l|}{ Seed } \\
\hline 1. & Low germination percentage & 02 & 3.3 & 4 \\
\hline 2. & Replacement of variety is very difficult & 06 & 10.0 & 3 \\
\hline 3. & Non-availability of seed material of new varieties & 31 & 51.7 & 1 \\
\hline 4. & Lack of knowledge about improved varieties & 16 & 26.7 & 2 \\
\hline \multicolumn{5}{|c|}{ Manures and fertilizers } \\
\hline 1. & Shortage of fertilizers & 02 & 3.3 & 2 \\
\hline 2. & Non-availability of manures/ fertilizers in time & - & - & - \\
\hline 3. & High cost of fertilisers & 53 & 88.3 & 1 \\
\hline 4. & Under bagging of fertilizers & 1 & 1.7 & 3 \\
\hline \multicolumn{5}{|c|}{ Insecticides and pesticides } \\
\hline 1. & Lack of knowledge on recommended pesticides for each pest and disease & 30 & 50.0 & 1 \\
\hline 2. & Non- availability of insecticides and pesticides in time & 05 & 8.3 & 3 \\
\hline 3. & Difficult to prepare the recommended concentration of solutions & 06 & 10.0 & 2 \\
\hline \multicolumn{5}{|c|}{ to } \\
\hline 1. & Non-availability of skilled labour & 02 & 3.3 & 4 \\
\hline 2. & Non-availability of labour during peak period & 06 & 10.0 & 3 \\
\hline 3. & High Cost of labour & 40 & 66.7 & 1 \\
\hline 4. & High labour requirement & 12 & 20.0 & 2 \\
\hline S.No & \multicolumn{4}{|l|}{ Technical Constraints } \\
\hline 1. & Improved technologies are not suitable to small and fragmented land holdings & 13 & 21.7 & 2 \\
\hline 2. & Lack of technical guidance regarding improved technologies & 13 & 21.7 & 2 \\
\hline 3. & Complications in adoption of improved technology & 14 & 23.3 & 1 \\
\hline 4. & Not able to solve the problem technically & 07 & 11.7 & 4 \\
\hline 5. & Non-availability of after sales services by companies & 02 & 3.3 & 6 \\
\hline 6. & Non-availability of spare parts locally & 05 & 8.3 & 5 \\
\hline S.No & \multicolumn{4}{|l|}{ Financial constraints } \\
\hline 1. & Rate of interest is very high & 09 & 15.0 & 3 \\
\hline 2. & Non availability of credit in time & 05 & 8.3 & 4 \\
\hline 3. & Complex, lengthy and rigid procedure of bank finance & 11 & 18.4 & 2 \\
\hline 4. & Inadequate quantity of credit & 14 & 23.3 & 1 \\
\hline 5. & Very low guidance on credit availability to farmers & 03 & 5.0 & 5 \\
\hline S.No & \multicolumn{4}{|l|}{ Constraints related to cost } \\
\hline 1. & High initial investment & 26 & 43.3 & 2 \\
\hline 2. & High cost of seed material & 01 & 1.70 & 3 \\
\hline 3. & High cost of fertilizers & & & \\
\hline 4. & High cost of pesticides and fungicides & & & \\
\hline 5. & High cost of labour for harvesting & 33 & 55.0 & 1 \\
\hline S.No & \multicolumn{4}{|l|}{ Marketing constraints } \\
\hline 1. & Fluctuations in market price & 21 & 35.0 & 2 \\
\hline 2. & Exploitation by middlemen & 07 & 11.7 & 3 \\
\hline 3. & High commission charges & 01 & 1.7 & 5 \\
\hline 4. & Low prices to the produce in market & 29 & 48.3 & 1 \\
\hline 5. & Markets are far away & 02 & 3.3 & 4 \\
\hline 6. & Lack of information regarding demand and supply & -- & -- & -- \\
\hline 7. & Delayed cash payment & -- & -- & -- \\
\hline 8. & Absence of support price in case of glut in the market & -- & -- & -- \\
\hline 9. & Inadequate physical facilities in market & -- & -- & -- \\
\hline S.No & \multicolumn{4}{|l|}{ General constraints } \\
\hline 1. & More incidence of pest and diseases & -- & -- & -- \\
\hline 2. & Irregular supply of electricity & - & - & - \\
\hline 3. & Lack of mechanization & 05 & 8.4 & 4 \\
\hline 4. & Fragmentation of land holdings & 01 & 1.6 & 5 \\
\hline 5. & Lack of insurance support & & & \\
\hline 6. & Lack of irrigation facilities & 12 & 20 & 2 \\
\hline 7. & Lack of soil and water testing facilities & -- & -- & -- \\
\hline 8. & Lack of information about government schemes and subsidies & - & - & - \\
\hline 9. & Occurrence of drought & 36 & 60.0 & 1 \\
\hline 10. & Deers and wild boars & 06 & 10.0 & 3 \\
\hline
\end{tabular}


The data (Table 3) on Technical constraints revealed that majority $(23.3 \%)$ were facing complications in adoption of improved technology. 21.6 percent expressed non suitability of improved technologies to small and fragmented land holdings $(21.6 \%)$ and lack of technical guidance regarding improved technologies are the next ranked major constraint.

Data (Table 3) on financial constraints indicated that majority $(23.3 \%)$ responded that credit given to them was inadequate for Groundnut cultivation. 18.3 percent expressed that procedure of bank finance is complex \& lengthy and 15 percent of them felt the rate of interest was very high.

When cost is studied as a constraint majority (55\%) expressed cost incurred on labour for harvesting was more and followed by high cost during initial investment (43.3\%)

The data (Table 3) on marketing constraints indicated that majority (48.3\%) expressed low price for the Groundnut and 35 percent felt fluctuations in market price was the next major constraint.

General constraints data (Table 3) indicated that majority $(60.0 \%)$ of the respondents expressed occurrence of drought was the major problem and $(20.0 \%)$ percent felt lack of irrigation facilities was the next major constraint.

It was concluded that Non - availability of new varieties of seed material, high cost of fertilisers, lack of knowledge on recommended pesticides for each pest and disease, high cost of labour, complications in adoption of improved technology, Inadequate quantity of credit, high cost of labour for harvesting, low market price to the produce and occurrence of drought perceived to be important constraints by majority of the respondents. These problems need to be solved through research institutions by identifying on the priority constraints of Groundnut of their region for a profitable solution. Socio economic, policy and infrastructure related issues affecting Groundnut productivity and production by dealing at government level for removing impediments in repealing the benefits of research outputs by farmers, and linkage with marketing and financial institutions for providing storage facility at least mandal level.

\section{References}

Banla, E.M., $\quad$ Daniel, K.D., $\quad$ Ifie, E.B., Samuel, K.O., Pangirayi, T and Haile, D. 2018. Groundnut production constraints and farmers' trait preferences: a pre-breeding study in Togo. Journal of Ethnobiology and Ethnomedicine.14:75.

Daudi, H., Shimelis, H., Laing, M., Okari, P and Mponda, O. 2018. Groundnut production constraints, farming systems and farmer preferred traits in Tanzania.

Hegde, D.M. importance of Groundnut in Indian Economy. 2017 In Recent Advances in Groundnut Production technology Krishna Reddy, G., Reddy P.V.R., and Reddy P.M.

Hemendra, S., Singh, N.K. and Kardam, D.K. 2014. Economic analysis of groundnut crop in Jaipur district of Rajasthan. Agriculture Update 9(1): 59-63.

Pasupuleti, J., Nigam, S., Pandey, M.K., Nagesh P., and Varshey R.K.2013. Groundnut improvement: Use of genetic and genomic tools. Frotiers in Plant science. 4:23.

Upadhyaya, H.D., Mukri, G., Nadaf, H.L and Singh, S. 2012. Variability and stability analysis for nutritional traits in the mini core collection of peanut. Crop Science 52: 168-178.

\section{How to cite this article:}

Veeraiah, A., V. Shilpakala, S. Ramalakshmi Devi and Ankaiah Kumar, K. 2019. Constraint Analysis of Groundnut Cultivation in YSR District of Andhra Pradesh, India. Int.J.Curr.Microbiol.App.Sci. 8(07): 1488-1493. doi: https://doi.org/10.20546/ijcmas.2019.807.176 